ORIGINAL ARTICLE

\title{
Long-term effects of plant spacing on the growth and morphometry of Bertholletia excelsa
}

\author{
Rafael Gonçalves de OLIVEIRA¹, Alex Soares de SOUZA², Victor Alexandre Hardt Ferreira dos SANTOS², \\ Roberval Monteiro Bezerra de LIMA ${ }^{3}$, Marciel José FERREIRA ${ }^{1 *}{ }^{*}$ \\ 'Universidade Federal do Amazonas, Departamento de Ciências Florestais, Av. General Rodrigo Octavio, 6200, Coroado I, CEP 69080-900, Manaus, AM, Brazil \\ ${ }^{2}$ Instituto Nacional de Pesquisas da Amazônia, Coordenação de Dinâmica Ambiental, Av. André Araújo, 2936, Aleixo, CEP 69060-001, Manaus, AM, Brazil \\ 3 Empresa Brasileira de Pesquisa Agropecuária, Embrapa, CEP 69010-970, Manaus, AM, Brazil \\ *Corresponding author: mjf.ufam@gmail.com; (1) https://orcid.org/0000-0002-7164-2284
}

\section{ABSTRACT}

Plant spacing is a potential driver of tree form and yield in forest plantations. However, its effects on the productivity of tree plantations in the Amazon are still little known. This study examined the effects of six spacing regimes $(3 \times 4,4 \times 4,4 \times 5,5 \times$ $5,5 \times 6$, and $6 \times 6 \mathrm{~m}$ ) on the growth and morphometry of a 20-year-old plantation of Bertholletia excelsa. We observed high, spacing-independent survival (> 70\%). For timber production purposes, intermediate and two large spacing regimes tended to higher values of yield components, mainly diameter, biomass, and volume, although some did not differ significantly from the smallest spacing. One of the intermediate spacings $(5 \times 5 \mathrm{~m})$ tended to higher commercial height. Tree crowns tended to be wider and longer in the larger spacings, which indicates the potential of these regimes for fruit production. Tree crowns exceeded the vital growth space in all spacing regimes, which suggests the need for thinning before the age of 20 years in all spacings to reduce intraspecific competition and increase yield. We estimated that a density of 84 remaining trees per hectare would be necessary to reach an average diameter of $40 \mathrm{~cm}$ at the age of 20 years. Thus, $B$. excelsa had high survival in the tested range of spacing regimes, while the intermediate and the largest spacing regimes led to better tree growth and morphometry.

KEYWORDS: Brazil-nut tree, silviculture, spacing, growth, productive plantation

\section{Efeitos de longo prazo do espaçamento de plantio no crescimento e morfometria de Bertholletia excelsa}

\section{RESUMO}

O espaçamento de plantio determina a forma e produtividade das árvores em plantaçóes florestais. Entretanto, seus efeitos sobre a produtividade de plantações de espécies arbóreas da Amazônia ainda são pouco compreendidos. Objetivou-se examinar os efeitos de seis regimes de espaçamento $(3 \times 4,4 \times 4,4 \times 5,5 \times 5,5 \times 6$, e 6 × $6 \mathrm{~m})$ sobre o crescimento e morfometria de plantaçôes de Bertholletia excelsa aos 20 anos de idade. Observamos alta sobrevivência independentemente do espaçamento (> 70\%). Para fins de produção de madeira, os regimes de espaçamento intermediário e dois maiores apresentaram valores mais altos de características de produção, principalmente diâmetro, biomassa e volume, embora alguns não diferiram significativamente do menor espaçamento. Um dos espaçamentos intermediários $(5 \times 5 \mathrm{~m})$ tendeu a maior altura comercial. As copas das árvores tenderam a ser mais largas e longas nos espaçamentos maiores, indicando potencial desses regimes para a produção de frutos. As copas das árvores excederam o espaço vital de crescimento em todos os espaçamentos, sugerindo a necessidade de desbaste antes dos 20 anos em todos os espaçamentos, para reduzir a competição intraespecífica e aumentar a produtividade. Estimamos que uma densidade de 84 árvores remanescentes por hectare seria necessária para atingir um diâmetro médio de $40 \mathrm{~cm}$ aos 20 anos. Portanto, $B$. excelsa apresentou alta sobrevivência em todos os regimes de espaçamento testados, enquanto os regimes de espaçamento intermediário e maiores proporcionaram melhor crescimento e morfometria das árvores.

PALAVRAS-CHAVE: castanheira do Brasil, silvicultura, espaçamento, crescimento, plantios de produçâo 


\section{INTRODUCTION}

There are many tree species of commercial interest in the Amazon region, but the use of native species in industrial plantations is still a challenge (Rolim et al. 2019; Nunes et al. 2020). In agroforestry systems, the inclusion of the native tree species Bertholletia excelsa Bonpl. is a common practice, especially among small farmers in the Brazilian Amazon region (Hoch et al. 2009). The main product of this species is the nut, which is among the main sources of income for Amazonian rural populations (Cronkleton et al. 2012). However, the species can also provide good quality wood (Borém et al. 2009), when it comes from reforestation, since felling wild specimens is prohibited by Brazilian legislation (Locatelli et al. 2015). In this sense, plantations are important to enable the use of the species' wood. The use of this species for reforestation of degraded areas in different planting systems has also been evaluated (Scoles et al. 2011; Ferreira et al. 2012). Regarding homogeneous plantations of B. excelsa, the company Agropecuária Aruanã, located in Central Amazonia, is the main example of a large-scale reforestation project using this species (Ferreira et al. 2016). However, silvicultural practices, such as spacing regime, have not yet been systematically defined for the best management of plantations.

To support public policies for the promotion of silviculture using native species, information on several aspects is required, such as quality of seed and seedling production, plant density, timing of thinning and pruning, and other aspects that may vary according to the planting location (Rolim et al. 2019). Despite important advances in scientific research and silvicultural techniques on native species in the Amazon region in recent decades (Tonini et al. 2005; dos Santos et al. 2020; Scoles and Gribel 2021), the still low representativeness of native species in industrial plantations is partly due to gaps in knowledge about the silvicultural aspects of these species and the management practices for the establishment and tending of plantations (Walters et al. 2005; Nunes et al. 2020).

The vital growth space of trees, determined by plant spacing, is one of the most important aspects during the planning and implementation of reforestation projects. This aspect will affect tree development, volumetric growth, wood quality, and production of fruit and wood per planted area (Botelho 1997; Inoue et al. 2011; Benomar et al. 2012). The selection of the most appropriate spacing regime depends on silvicultural and ecophysiological characteristics of the planted species, planting purpose, site quality, and management practices (Smith and Strub 1990; Botelho 1997). Analyses of morphometric parameters, such as diameter and crown area, can indicate the best spacing for the cultivation of each species (Tonini and Arco-Verde 2005). Morphometric variables can predict stability, vitality, yield, degree of competition, the space occupied by each tree, and even the adequate period for thinning (Durlo and Denardi 1998; Tonini and ArcoVerde 2005).

Larger spacings can increase plant diameter from the positive relationship between crown diameter and diameter at breast height (Tonini and Arco-Verde 2005). Nevertheless, the positive relationship between crown length and diameter at breast height (Tonini and Arco-Verde 2005) suggests that a larger crown due to a large spacing regime may result in lower commercial height. In turn, the fruit production of $B$. excelsa correlates positively with diameter at breast height and crown length (Tonini et al. 2008), which suggests that larger spacings may favor fruit production.

Thus, the knowledge about the effects of spacing on tree growth is essential to guide the most appropriate practices for the establishment and management of stands. In this sense, defining the most suitable spacing regimes for $B$. excelsa can contribute to optimize yield and increase the planted area. We specifically sought to analyze whether: $i$ ) spacing regimes affect the survival and growth of $B$. excelsa trees; and ii) plant spacing influences crown morphometry in $B$. excelsa trees.

\section{MATERIAL AND METHODS}

\section{Study site and experimental design}

We collected dendrometric and morphometric data from B. excelsa plantations of the company Agropecuária Aruanã in Amazonas State, Brazil (0300'29”S, 5849'53"W) (Figure 1). According to the Köppen-Geiger classification system, the climate of the region is Af, and the predominant vegetation is equatorial tropical forest (Alvares et al. 2013). The rainfall regime (1980-2019) includes a wet season (January to May), with a monthly average of $319 \mathrm{~mm}$, and a dry season (August to September), with a monthly average of $76 \mathrm{~mm}$ (allways below $100 \mathrm{~mm}$ ). Average annual rainfall and temperature are $2,483 \mathrm{~mm}$ and $27.1^{\circ} \mathrm{C}$, respectively (INMET 2020). The predominant soil is a Dystrophic Yellow Latosol (IBGE

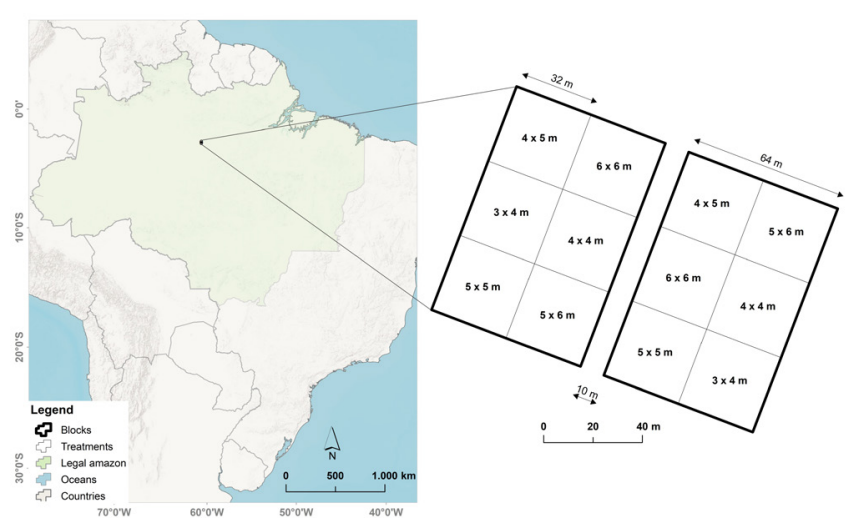

Figure 1. Location of the study area and a scheme of the experimental plots of a 20-year-old Bertholletia excelsa plantation at different spacings (indicated on each plot) in Amazonas state, Brazil. This figure is in color in the electronic version. 
2019), with mostly very clayey texture (Ferreira et al. 2016), high acidity $(\mathrm{pH} 4.2)$, high aluminum content $\left(1.08 \mathrm{cmol}_{\mathrm{c}}\right.$ $\left.\mathrm{dm}^{-3}\right)$, low cation exchange capacity $\left(2.03 \mathrm{cmol}_{c} \mathrm{dm}^{-3}\right)$, and medium organic matter content $\left(43.3 \mathrm{~g} \mathrm{~kg}^{-1}\right)$ up to $10 \mathrm{~cm}$ depth (Ronquim 2010; Lima and Souza 2014; Brasil et al. 2020).

The planting of B. excelsa stands took place in March 1996 , in areas previously used for pasture. The seedlings grew in nurseries on the property and came from seeds of selected matrices located on the property. The planting procedure included mechanical soil grading, and no fertilizers were used during or after planting. A total of 566 seedlings aged 12 to 18 months and an average height of $40 \mathrm{~cm}$ were planted in six spacing regimes $(3 \times 4 \mathrm{~m} ; 4 \times 4 \mathrm{~m} ; 4 \times 5 \mathrm{~m} ; 5 \times 5 \mathrm{~m} ; 5 \times 6$ $\mathrm{m}$; and $6 \times 6 \mathrm{~m}$ ), with two plots for each treatment (Table 1; Figure 1). The useful plot consisted of all trees within a plot, excluding the border row.

Table 1. Number of Bertholletia excelsa trees planted in 1996 in plots at different spacings in an experimental plantation in Amazonas state (Brazil) and useful trees per plot and treatment.

\begin{tabular}{ccccc}
\hline Spacing & $\begin{array}{c}\text { Trees } \\
\text { per plot }\end{array}$ & $\begin{array}{c}\text { Useful trees } \\
\text { per plot }\end{array}$ & $\begin{array}{c}\text { Total } \\
\text { trees }\end{array}$ & $\begin{array}{c}\text { Total } \\
\text { useful trees }\end{array}$ \\
\hline $3 \times 4 \mathrm{~m}$ & 80 & 48 & 160 & 96 \\
\hline $4 \times 4 \mathrm{~m}$ & 64 & 36 & 128 & 72 \\
\hline $4 \times 5 \mathrm{~m}$ & 48 & 24 & 96 & 48 \\
\hline $5 \times 5 \mathrm{~m}$ & 36 & 16 & 72 & 32 \\
\hline $5 \times 6 \mathrm{~m}$ & 30 & 12 & 60 & 24 \\
\hline $6 \times 6 \mathrm{~m}$ & 25 & 9 & 50 & 18 \\
\hline TOTAL & $\mathbf{2 8 3}$ & $\mathbf{1 4 5}$ & $\mathbf{5 6 6}$ & $\mathbf{2 9 0}$ \\
\hline
\end{tabular}

\section{Survival, dendrometric, and morphometric measurements}

We collected the data 20 years after planting (between July and September 2016). We calculated survival (S) as the ratio between the number of individuals present at the time of survey and the number of individuals planted in each useful plot. We measured the diameter at breast height $(\mathrm{DBH})$ and total height $(\mathrm{TH})$ of all individuals in the useful plots. DBH was determined by measuring the circumference at breast height (1.3 $\mathrm{m}$ from the ground) with a measuring tape. To determine TH, we used a Haglöf hypsometer (Haglöf Sweden?, Model ECII, Sweden).

We measured crown variables in six trees per plot, totaling 12 trees per treatment. The sampling was randomized but with a restriction of a minimum distance of six meters between tree stems. We measured crown diameter (CD) between and within planting rows. We considered crown length $(\mathrm{CL})$ as the difference between $\mathrm{TH}$ and the height of the lowest alive branch, measured with a laser measuring tool (Bosch', model GLM40). We calculated the projected crown area (PCA) using the ellipse area formula $\left(\mathrm{m}^{2}\right)$ according to Scoles et al. (2016):
Ellipse area $=\left(C R_{1} \times C R_{2}\right) \times \pi$

where: $C R_{n}=$ crown radius $\left(C D_{n} \cdot 2^{-1}\right)$

From the TH and CL measurements, we calculated the crown ratio (CR) according to Tonini et al. (2008):

$C R=C L / T H \times 100$

where: $C R=$ crown ratio; $C L=$ crown length; and $T H=$ total height

Commercial height $(\mathrm{CH})$ corresponded to the height of the lowest alive branch, measured with a laser measuring tape (Bosch', model GLM40). The mean annual increment in diameter (MAId) and the mean annual increment in height (MAIh) were estimated from the ratio between diameter or height and the age of the tree.

\section{Destructive sampling and modelling}

We made a destructive sampling per diametric class in each spacing regime. This classification followed the Sturges formula (3), which considers the number of individuals (Machado and Figueiredo Filho 2006). In each diametric class, we chose one tree with a $\mathrm{DBH}$ value close to the average value of the class. Therefore, we selected 5 to 7 trees in each spacing regime, totaling 36 trees.

$$
K=1+3.3 \cdot \log \log n
$$

where: $K=$ number of classes; $n=$ number of observations

We measured stem volume (SV) through rigorous cubing by the Smalian method (Leite et al. 2006). We sectioned trees every two meters up to a limit diameter of $5 \mathrm{~cm}$. To determine aboveground biomass (AB), stem biomass ( $\mathrm{SB})$, branch biomass (BB), and leaf biomass (LB), we analyzed leaves (Le), branches $(\mathrm{Br})$, and stem $(\mathrm{St})$ following Higuchi et al. (1998). For that, we weighed these plant parts in the field with a mechanical platform scale (Micheletti, MIC 2A) with a capacity of $200 \mathrm{~kg}$ and an accuracy of $100 \mathrm{~g}$. We calculated dry biomass from 3-cm aliquots of discs along the stem and branches (base, middle, and apex) and aliquots of 30 leaves from each third of the crown (lower, middle, and upper). We immediately weighed these aliquots in the field on a digital scale (Uranus, US 20/2 POP-S) and sent them to the laboratory for oven drying at $100-105{ }^{\circ} \mathrm{C}$ for a minimum of 72 hours (Cienlab, CE 220/81) or until constant weight. We dried the leaves at $70{ }^{\circ} \mathrm{C}$ for a minimum of 48 hours. We calculated the coefficient for biomass extrapolation $(k)$ from the ratio between dry and fresh biomass of aliquots according to equation (4). For extrapolation, we used equation (5).

$$
k=M_{d} M_{f}^{-1}
$$

where: $k=$ coefficient; $M_{d}=$ dry mass; and $M_{f}=$ fresh mass

$M_{d}=k \cdot M_{f}$

where: $M_{d}=$ dry biomass; $k=$ coefficient; and $M_{f}=$ fresh biomass 
From the adjusted equations, we estimated the volume and biomass of uncut trees. The choice of the best models followed the criteria of higher adjusted determination coefficient $\left(\mathrm{R}^{2}{ }_{\text {adj }}\right)$, lower estimation standard error $\left(\mathrm{S}_{\mathrm{vy}}\right)$, uniformity and no bias in residual distribution (Res\%) (Sanquetta et al. 2014). The selection of the best model considered the difficulty in obtaining height data in the field. We adjusted nonlinear allometric models by the nonlinear least square method using the Gauss-Newton iterative process. For that, we used the function $n l s$ of the package stats of the statistical software $\mathrm{R}$ ( $\mathrm{R}$ Core Team 2020). The equation to estimate stem volume followed the nonlinear Schumacher-Hall model $\left(\mathrm{R}^{2}{ }_{\mathrm{adj}}=0.94\right.$ and $\left.S_{y x}=0.10\right)$. We selected the nonlinear model of BerkhoutHusch for aboveground biomass $\left(\mathrm{R}^{2}=0.91\right.$ and $\left.\mathrm{S}_{\mathrm{yx}}=102.97\right)$ and for stem biomass $\left(\mathrm{R}_{\text {adj }}^{2}=0.92\right.$ and $\left.S_{\mathrm{yx}}=71.24\right)$; and the modified nonlinear model of Schumacher-Hall for branch biomass $\left(\mathrm{R}_{\text {adj }}^{2}=0.83\right.$ and $\left.\mathrm{S}_{\mathrm{yx}}=31.28\right)$ and for leaf biomass $\left(\mathrm{R}^{2}{ }_{\text {adj }}=0.83\right.$ and $\left.S_{y x}=7.88\right)$ (Table 2).

\section{Statistical analyses}

We performed analysis of variance (ANOVA) to test plant spacing effects on growth and crown morphometry variables, with exception of $\mathrm{CR}$ and survival, which analyzed with the Kruskal-Wallis rank test and the Dunn test $(\mathrm{P}<0.05)$, which is more appropriate for proportion variables. Prior to ANOVA, we analyzed the assumptions of normality (Shapiro-Wilk test) and homogeneity of variance (Levene test). We transformed data that did not meet the assumptions using the square root function (CL, PCA, SV), logarithmic function (AB, SB, $\mathrm{BB}$ ), or Box-Cox function (LB). We performed the Duncan post hoc test $(P<0.05)$ after ANOVA to make pairwise comparisons among plant spacings. We have also developed a nonlinear model of PCA as a function of DBH to estimate the vital growth space needed for trees to reach a target diameter at the age of 20 years. We performed all statistical analyses using the packages stats, car, and agricolae of software R (Fox and Weisberg 2019; Mendiburu 2020; R Core Team 2020).

\section{RESULTS}

\section{Survival and growth}

Survival was above $70 \%$ in all spacing regimes and ranged from $71 \%$ (5 x 6-m spacing) to $92 \%$ ( 4 x 4 m). Despite this amplitude, there was no significant difference among treatments (Figure 2).

The magnitude of differences among spacings for TH and $\mathrm{DBH}$ was 35 and $95 \%$, respectively, with a tendency for higher values in one intermediate $(5 \times 5 \mathrm{~m})$ and the two larger spacings, which mostly differed significantly from the $5 \times 4$ and $4 \mathrm{x} 4-\mathrm{m}$, spacings, but less so from the smallest spacing $(3 \times 4 \mathrm{~m})$ (Figure 3a, b). The same magnitude of differences occurred for MAId and MAIh, respectively (Figure 4). The 5 x 5-m spacing resulted in a 0.8 -fold higher average $\mathrm{CH}$ than

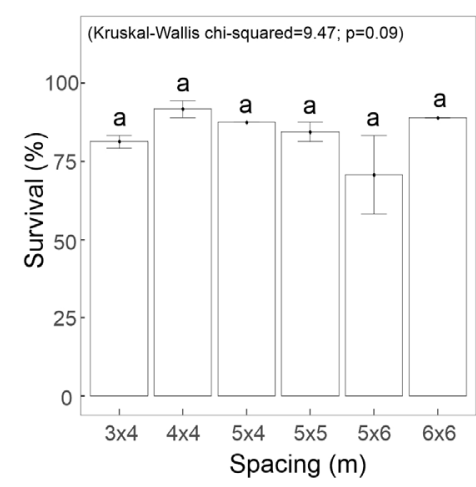

Figure 2. Survival after 20 years of Bertholletia excelsa planted in plots at different spacings in an experimental plantation in Amazonas state, Brazil. Each column represents the mean of two plots, and the bar the standard error $(n=12 ; d f=5)$.
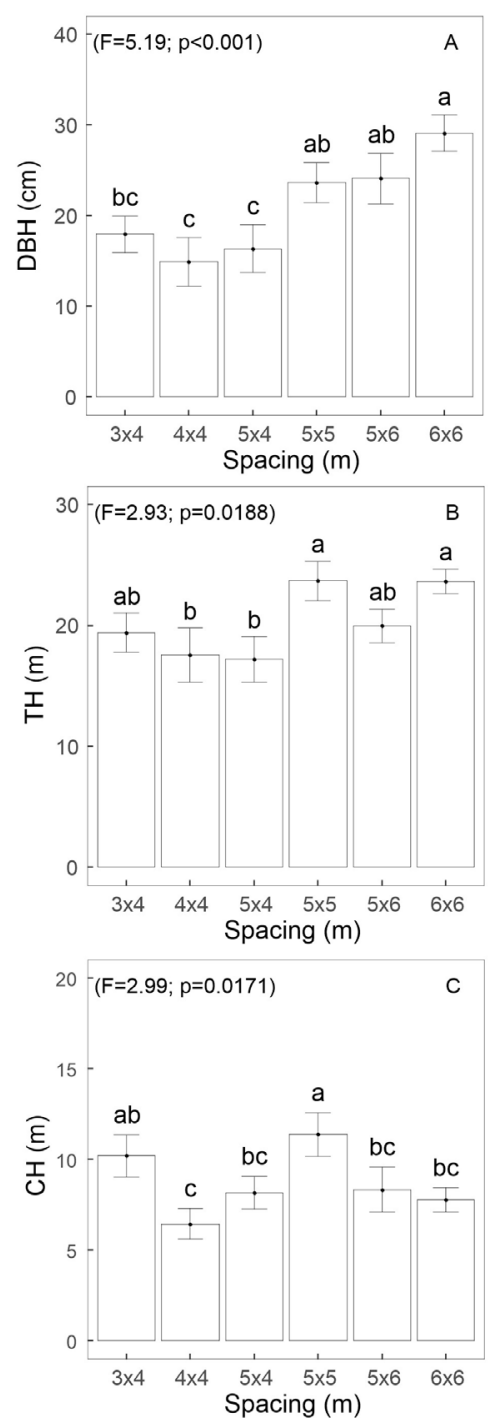

Figure 3. Diameter at breast height (DBH) (A); total height (TH) (B); and commercial height $(\mathrm{CH})(\mathrm{C})$ of 20-year-old Bertholletia excelsa trees planted in plots at different spacings in an experimental plantation in Amazonas state, Brazil. Each column represents the mean of 12 trees, and the bar the standard error $(n=72 ; d f=5,66)$. 
Table 2. Regression statistical parameters and equations to estimate stem volume (SV), aboveground biomass (AB), stem biomass (SB), branch biomass (BB), and leaf biomass (LB) in a 20-year-old Bertholletia excelsa experimental plantation at different spacings (between $3 \times 4$ and $6 \times 6 \mathrm{~m})$ in Amazonas state, Brazil $(n=36$; $\mathrm{df}=33$ or 34).

\begin{tabular}{|c|c|c|c|c|c|}
\hline Variable & Model & Equation & $\mathbf{R}_{\text {adj }}^{2}$ & $S_{y \cdot x}$ & AIC \\
\hline \multirow{6}{*}{ Volume } & Husch & $V=0.0002^{n s}+D B H^{2.3514 *}$ & 0.89 & 0.13 & 40.23 \\
\hline & Kopezky-Gehrardt & $V=-0.0614^{\text {ns }}+0.0009^{*} D B H^{2}$ & 0.90 & 0.13 & 39.01 \\
\hline & Hohenadl-Krenm & $V=0.0461^{n s}-0.0110^{n s} D B H+0.0011^{*} D B H^{2}$ & 0.90 & 0.13 & 37.95 \\
\hline & Dissescu-Meyer & $V=-0.0067^{n s} D B H+0.0010^{*} D B H^{2}$ & 0.90 & 0.13 & 39.79 \\
\hline & Spurr & $V=0.0019^{n s}+0.00004^{*} D B H^{2} H T$ & 0.94 & 0.10 & 59.85 \\
\hline & Schumacher-Hall & $V=0.00002^{n s}+D B H^{1.8010 *} H T^{1.4410 *}$ & 0.94 & 0.10 & 60.57 \\
\hline \multirow{5}{*}{ Aboveground Biomass } & Berkhout-Husch & $B I O=0.3164^{n s}+D B H^{2.2332 *}$ & 0.91 & 102.97 & 439.78 \\
\hline & Kopezky-Gehrardt & $B I O=-53.4102^{\text {ns }}+\emptyset_{1} D B H^{0.7683 *}$ & 0.92 & 100.02 & 438.73 \\
\hline & Hohenadl-Krenm & $B I O=-33.9723^{n s}-1.9816^{n s} D B H+0.8108^{*} D B H^{2}$ & 0.91 & 101.40 & 440.68 \\
\hline & Schumacher-Hall & $\left.B I O=0.3893^{*}+D B H^{2.2841 *} H^{-0.1430 \text { ns }}\right)$ & 0.91 & 101.81 & 439.89 \\
\hline & Spurr & $B I O=42.1438^{n s}+0.0411^{*} D B H^{2} H C$ & 0.78 & 162.63 & 473.74 \\
\hline \multirow{5}{*}{ Stem Biomass } & Berkhout-Husch & $B F U=0.3194^{n s}+D B H^{2.1535}$ & 0.92 & 71.24 & 413.27 \\
\hline & Kopezky-Gehrardt & $B F U=-31.3634^{n s}+0.5780^{*} D B H^{2}$ & 0.93 & 69.06 & 412.06 \\
\hline & Hohenadl-Krenm & $B F U=-42.0158^{n s}+1.0859^{\text {ns }} D B H+0.5547^{*} D B H^{2}$ & 0.93 & 70.03 & 414.03 \\
\hline & Schumacher-Hall & $B F U=0.3519^{\text {ns }}+D B H^{2.1757^{*}} H T^{-0.0644^{n s}}$ & 0.92 & 71.90 & 414.85 \\
\hline & Spurr & $B F U=35.6730^{\text {ns }}+0.0315^{*} D B H^{2} H C$ & 0.82 & 110.54 & 445.93 \\
\hline \multirow{7}{*}{ Branch Biomass } & Berkhout-Husch & $B F U=0.0305^{n s}+D B H^{2.4218^{*}}$ & 0.69 & 42.43 & 375.95 \\
\hline & Kopezky-Gehrardt & $B F U=-17.9814^{n s}+0.1513^{*} D B H^{2}$ & 0.71 & 41.47 & 315.34 \\
\hline & Hohenadl-Krenm & $B F U=-1.3051^{n s}-1.7000^{n s} D B H+0.187^{*} D B H^{2}$ & 0.70 & 41.94 & 377.12 \\
\hline & Schumacher-Hall & $B F U=0.0463^{n s}+D B H^{2.5649^{*}} H T^{-0.3417^{n s}}$ & 0.70 & 41.26 & 374.86 \\
\hline & Spurr & $B F U=5.5453^{n s}+0.0076^{*} D B H^{2} H C$ & 0.53 & 53.01 & 393.03 \\
\hline & Schumacher-Hall (2) & $B F U=0.0021^{n s}+D B H^{1.5250^{*}} D C^{2.6220^{*}}$ & 0.83 & 31.28 & 354.92 \\
\hline & Spurr (2) & $B F U=-8.1845^{n s}+0.0159^{*} D B H^{2} D C$ & 0.80 & 34.57 & 362.25 \\
\hline \multirow{7}{*}{ Leaf Biomass } & Berkhout-Husch & $B G A=0.0017^{\text {ns }}+D B H^{2.8621}$ & 0.74 & 9.91 & 271.27 \\
\hline & Kopezky-Gehrardt & $B G A=-4.0653^{n s}+0.0391^{*} D B H^{2}$ & 0.73 & 10.25 & 274.75 \\
\hline & Hohenadl-Krenm & $B G A=9.3485^{n s}-1.3675^{\text {ns }} D B H+0.0684^{*} D B H^{2}$ & 0.74 & 10.06 & 274.29 \\
\hline & Schumacher-Hall & $B G A=0.0029^{n s}+D B H^{2.9380^{*}} H T^{-0.2942^{n s}}$ & 0.74 & 9.81 & 277.80 \\
\hline & Spurr & $B G A=0.9255^{n s}+0.0021^{*} D B H^{2} H C$ & 0.61 & 12.29 & 287.78 \\
\hline & Schumacher-Hall (2) & $B G A=0.0002^{n s}+D B H^{2.3736^{*}} D C^{1.7744^{*}}$ & 0.83 & 7.88 & 255.66 \\
\hline & Spurr (2) & $\mathrm{BGA}=0.9255^{n s}+0.0021^{*} D B H^{2} H C$ & 0.82 & 8.33 & 259.80 \\
\hline
\end{tabular}

$\mathrm{R}_{\text {adj }}^{2}=$ adjusted coefficient of determination; $S_{y x}=$ estimate standard error; $\mathrm{DHB}=$ diameter at breast height $(\mathrm{cm}) ; \mathrm{TH}=$ total height $(\mathrm{m}) ; \mathrm{CH}=\mathrm{commercial}$ height (m). ${ }^{*}$ Significant coefficients at $5 \%$ by t-test. ${ }^{\text {ns }}$ Nonsignificant coefficients at $5 \%$ by t-test. 

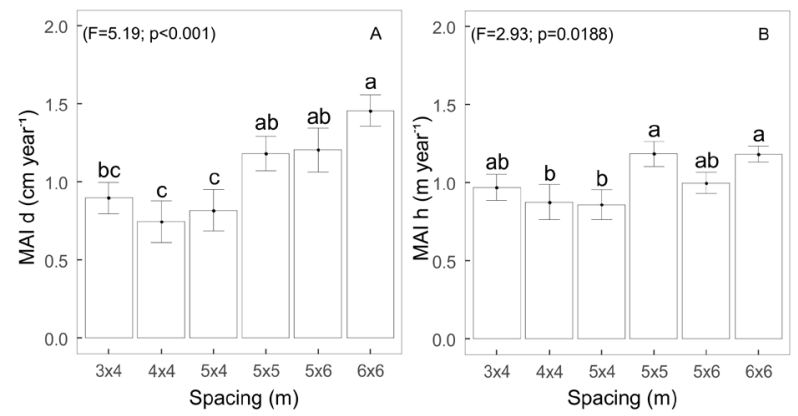

Figure 4. Mean annual increment in diameter (MAld) (A) and mean annual increment in height (MAlh) (B) of 20-year-old Bertholletia excelsa trees planted in plots at different spacings in an experimental plantation in Amazonas state, Brazil. Each column represents the mean of 12 trees, and the bar the standard error $(n=72 ; d f=5,66)$.

in the lowest-yield spacing for this parameter $(4 \times 4 \mathrm{~m})$, with a tendency for higher values in one of the intermediate spacings $(5 \times 5 \mathrm{~m})$, that mostly differed significantly from the other spacings, except for the smallest $(3 \times 4 \mathrm{~m})$, which had the second highest value (Figure 3c). One of the intermediate ( 5 $\times 5 \mathrm{~m})$ and the largest spacings $(5 \times 6 \mathrm{~m} ; 6 \times 6 \mathrm{~m})$ resulted in the highest $\mathrm{DBH}$ and MAId values, although in some cases there was no significant difference with the smallest spacing (3 4 m) (Figure 3a, 4a). Regarding TH and MAIh, although there was not much difference among treatments, a tendency for higher values and increments in the intermediate $(5 \times 5$ $\mathrm{m})$ and one of the large $(6 \times 6 \mathrm{~m})$ spacings (Figure $3 \mathrm{~b}, 4 \mathrm{~b})$.

The intermediate $5 \times 5-\mathrm{m}$ spacing also stood out in terms of volumetric yield per hectare, with approximately $11.2 \mathrm{~m}^{3}$ $\mathrm{ha}^{-1}$ year $^{-1}$, discounting mortality, followed by the smallest spacing $(3 \times 4 \mathrm{~m})$, with $10.9 \mathrm{~m}^{3} \mathrm{ha}^{-1}$ year ${ }^{-1}$, the largest spacing $(6 \times 6 \mathrm{~m})$ with $9.9 \mathrm{~m}^{3} \mathrm{ha}^{-1}$ year- $^{-1}$, the $4 \times 4$ - $\mathrm{m}$ spacing, with $9,4 \mathrm{~m}^{3} \mathrm{ha}^{-1}$ year $^{-1}, 5 \times 4 \mathrm{~m}$ with $6.5 \mathrm{~m}^{3} \mathrm{ha}^{-1}$ year $^{-1}$, and $5 \times 6$ $\mathrm{m}$ with $5.6 \mathrm{~m}^{3} \mathrm{ha}^{-1}$ year ${ }^{-1}$.

\section{Morphometry}

Spacing significantly affected CL, CD, and PCA, and, overall, crown measurements tended to increase with spacing (Figure 5). The average values of CL, CD, and PCA in the smallest spacing were $0.7,0.7$, and 1.7 -fold higher than in the largest spacing. The projected crown area (PCA) exceeded the spacing limit in all regimes (Figure 5) and exceeded the vital growth space by $1.4,0.8,0.5,0.9,0.9$, and 1.2 -fold in the spacing regimes $3 \times 4,4 \times 4,5 \times 4,5 \times 5,5 \times 6$, and $6 \times 6$ $\mathrm{m}$, respectively. The average value of CR was $43 \%$ higher in the largest compared to the smallest spacing, although there was not a clear significant difference among the intermediate spacings (Figure 5). There was a significant $\left(\mathrm{R}^{2}{ }_{\text {adj }}=0.78 ; \mathrm{P}<\right.$ 0.001 ) and exponential relationship between PCA and DBH (Figure 6), from which we estimated that 84 remaining trees per hectare (vital growth space of $119 \mathrm{~m}^{2}$ ) would be necessary
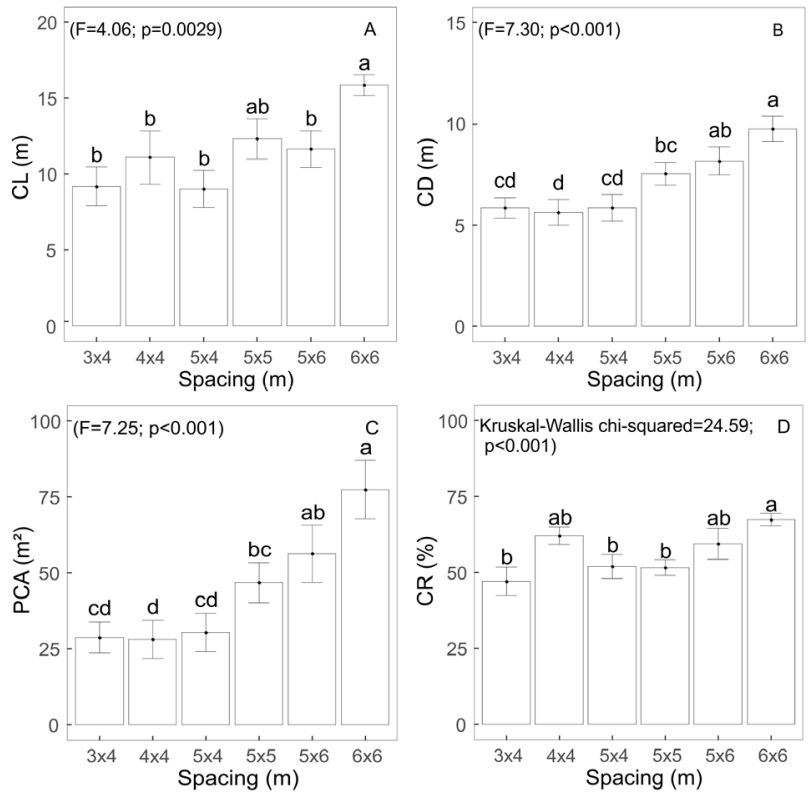

Figure 5. Crown length (CL) $(A)$; crown diameter (CD) (B); projected crown area (PCA) (C); and crown ratio (CR) (D) of 20-year-old Bertholletia excelsa trees planted in plots at different spacings in an experimental plantation in Amazonas state, Brazil. Each column represents the mean of 12 trees, and the bar the standard error $(n=72 ; d f=5,66)$.

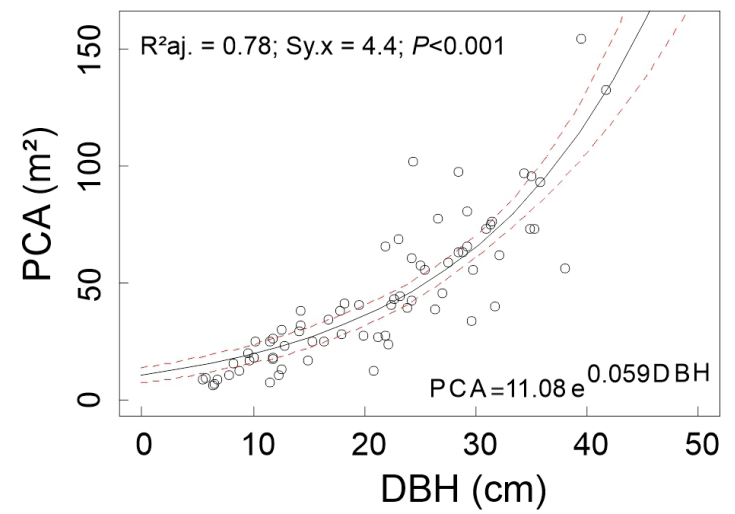

Figure 6. Ratio between projection crown area (PCA) and diameter at breast height (DBH) in 20-year-old Bertholletia excelsa trees planted in plots at different spacings in an experimental plantation in Amazonas state, Brazil. Circles = observed values; solid black line $=$ estimated mean values; dashed lines $=95 \%$ confidence interval of the estimates; $(n=72 ; d f=69)$.

for the trees to reach an average diameter of $40 \mathrm{~cm}$ at the age of 20 years.

\section{Volume and biomass}

Spacing significantly affected volume and biomass variables ( $S V, A B, S B, B B$, and $L B)$, which tended to significantly higher values in the three largest spacing regimes (Figure 7). The average values of SV, AB, SB, BB, and LB in the three largest spacing regimes were 106, 117, 115, 234, and $231 \%$ higher than those of the three smallest. Likewise, at the population level, the three largest spacings had higher 

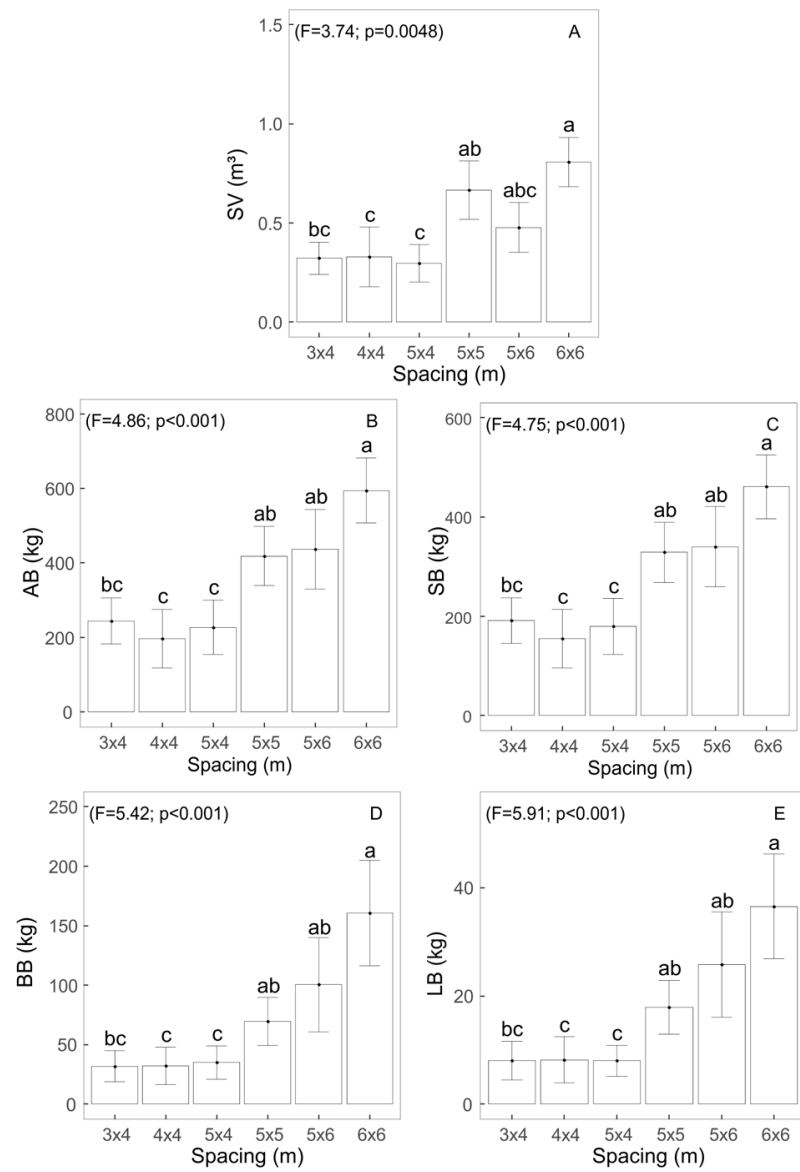

Figure 7. Stem volume (SV) (A); aboveground dry biomass (AB) (B); stem dry biomass (SB) (C); branch dry biomass (BB) (D); and leaf dry biomass (LB) (E) of 20-year-old Bertholletia excelsa trees planted in plots at different spacings in an experimental plantation in Amazonas state, Brazil. Each column represents the mean of 12 trees, and the bar the standard error $(n=72 ; d f=5,66)$.

biomass above ground (average $122 \mathrm{~kg} \mathrm{ha}^{-1}$ ) compared to 112 $\mathrm{kg} \mathrm{ha}^{-1}$ for the three smallest spacings.

\section{DISCUSSION}

Bertholletia excelsa has been highly persistent in disturbed sites, with recorded survival rates between $77 \%$ and $100 \%$, even in low-light environments (Scoles et al. 2011, 2014; Lima and Souza 2014), despite divergent results by some studies, possibly attributed to low light or severe predation by rodents (Oliveira 2000; Scoles and Gribel 2021). It is noteworthy in our study that $B$. excelsa survival was high even twenty years after planting in an area previously used for grazing, independently of the spacing regime. Smaller spacing regimes generally increase intraspecific competition, mainly for light, increasing tree mortality in forest plantations during crown closure (Will et al. 2010; Akers et al. 2013; Schneider et al. 2015). However, photosynthetic plasticity in B. excelsa enhances survival in contrasting light environments (Souza et al. 2017; Lopes et al. 2019), which may have contributed to the spacing-independent survival in our study. It is also possible that the smallest spacing in our study may not have been sufficient to induce high intraspecific competition and higher mortality, which could have occurred in the denser spacings currently used in production forests.

A larger plant spacing allows better crown development and, consequently, more biomass allocation to branches, improving crown projection area and crown length (Sanquetta et al. 2003). For timber production purposes, the two largest spacings in our study led to the best yields, yet the intermediate spacing of $5 \times 5 \mathrm{~m}$ tended to lower values of crown length and crown ratio, consequently providing a higher commercial height in comparison to the largest spacings. The $5 \times 5-\mathrm{m}$ spacing also stood out in terms of volumetric yield per hectare. Hence, our results suggest that a $5 \times 5$-m spacing is better than the larger ones tested to obtain $B$. excelsa trees with a higher $\mathrm{CH}$ and volume for timber production. Although there were no no significant differences between the $5 \times 5$ and $3 \times 4-m$ spacings for some parameters, the $5 \times 5$-m regime tended to higher commercial height and volume. Other studies have found different results for $B$. excelsa and other native species. In the same study area, Lima and Souza (2014) recommended the $3 \times 4$-m spacing regime as an initial spacing for $B$. excelsa due to the higher production per hectare at the age of 15 years. However, the authors did not consider commercial height. Oliveira et al. (2018) analyzed 38-year-old Cariniana legalis (Mart.) Kuntze trees and found greater individual growth in the largest tested spacing of $3 \times 2.5 \mathrm{~m}$. Notwithstanding, their smallest spacing $(3 \times 1.5 \mathrm{~m})$ was more advantageous, since it provided a larger volume of wood $\left(17 \mathrm{~m}^{3} \mathrm{ha}^{-1}\right.$ year versus $14 \mathrm{~m}^{3}$ ha $^{-1}$ year $^{-1}$ in the largest spacing), although this wood was less dense in comparison to that of trees grown in larger spacings.

Regarding fruit production, B. excelsa trees with wide crowns and in better shape are more productive than those with suppressed crowns (Kainer et al. 2007; Tonini et al. 2008; Scoles et al. 2016). In native stands, for example, B. excelsa trees with higher CR values (over $47 \%$ ) have higher fruit production; i.e., trees with longer crowns were more productive (Tonini et al. 2008). In our study, crown morphometric variables and biomass allocation to branches and leaves increased with spacing after 20 years, and, although we did not measure fruit production, we can assume that the more structured and leafy crown of trees grown with the larger spacings is a good approximation of the fruit production potential. Moreover, trees with large crowns accumulated high amounts of biomass at the whole-tree and stand level. The biomass accumulation in our $B$. excelsa stands - at the age of 20 years - corroborates observations in neotropical secondary forests (Poorter et al. 2016). These stands have high carbon sequestration potential and therefore can meet reforestation goals. Crown measurements are also important for the management of tropical tree plantations. Determining the 
crown diameter, for example, is of fundamental importance since it allows to design the vital growth space for each tree (Dionisio et al. 2018). Tonini and Arco-Verde (2005) estimated that it would take a maximum of 281 remaining trees per hectare (spacing of $6 \times 6 \mathrm{~m}$ ) for $B$. excelsa trees to reach an average diameter of $14 \mathrm{~cm}$ at seven years of age, i.e., a mean annual increment in diameter (MAId) of $2 \mathrm{~cm}_{\text {year }}{ }^{-1}$. Using the same adjustment equation of these authors to reach a DBH of $40 \mathrm{~cm}$, we obtained the value of 85 remaining trees per hectare (spacing of $11 \times 11 \mathrm{~m}$ ), supporting the result of our study.

Another crown trait of great importance for planting management is the crown ratio (CR), which is the ratio between crown length and tree height. The trend to lower $\mathrm{CR}$ values with reduced spacing may be due to increased competition for light. The greater shading among individuals can stimulate natural pruning and reduce the live crown ratio (Onyekwelu et al. 2011). Crown ratio is a common indicator of tree vigor (Comfort et al. 2010), determining the time for thinning and the potential response of trees (Dyer and Burkhart 1987). Moreover, this index can be an indirect indicator of photosynthetic capacity, with application in forest growth and production models (Leites et al. 2009). The normal rates of diameter growth in Pinus sp. trees remain unaffected if the CR is $40 \%$ or higher, and thinning should take place soon after the CR average drops below 50\% (Harrington 2001). Considering only this criterion, only the smallest spacing regime $(3 \times 4 \mathrm{~m})$ in our study would require thinning, however it has to be considered that Pinus sp is a fast-growing exotic gymnosperm that is phylogenetically distant from B. excelsa. Furthermore, the exponential model of PCA as a function of DBH indicated that thinning should take place before the age of 20 years to give enough space for the trees to reach a DBH of $40 \mathrm{~cm}$. Additional studies on ring-growth or permanent plots are necessary to reconstruct the curve of the mean annual increment (MAI) and current annual increment (CAI) in different spacings to determine the best time for thinning.

Our results show that $B$. excelsa has planting potential even in dense spacing due to its tolerance to intraspecific competition, however, wider spacing regimes must be evaluated to further test to support these results. Nevertheless, the intermediate spacing of $5 \times 5 \mathrm{~m}$ has an advantage in terms of $\mathrm{CH}$, and volumetric yield per hectare. Our study also showed the importance of monitoring both morphometric and dendrometric variables such as PCA and DBH to determine the ideal period for thinning. The model adjusted to the PCA values as a function of DBH can be used to plan the number of trees to be maintained in the plantation considering a target diameter to meet the demand for roundwood.

\section{CONCLUSIONS}

Our main findings on Bertholletia excelsa grown over 20 years in spacing regimes from $3 \times 4$ to $6 \times 6$ m were: i) high survival was spacing-independent; ii) $B$. excelsa is a good option for reforestation purposes due to its long-term survival in several spacings, even in environments previously used for pasture; iii) tree growth increased with the spacing regime; iv) spacing influenced morphometric parameters, with implications for timber and fruit production and forest management; v) the intermediate spacing of $5 \times 5$ m lead to the best timber yield as trees had larger commercial height and trended to larger volumetric yield per hectare; vi) larger spacings also provided trees with larger diameters and crowns with potential for fruit production; and vii) thinning should probably take place before trees reach the age of 20 years for all tested spacing regimes.

\section{ACKNOWLEDGMENTS}

This study was partially financed by Coordenaçáo de Aperfeiçoamento de Pessoal de Nível Superior - CAPES (Brazil) (Finance Code 001). We thank Fundaçấo de Amparo à Pesquisa do Estado do Amazonas -FAPEAM (Brazil) (Edital 005/2019 - PAPAC, 062.00920/2019), Agropecuária Aruanã for allowing this study to be carried out in their property and for the support in logistics, and Embrapa Amazônia Ocidental, which originally installed and conducted the experiment in the area. We are also grateful to the Laboratory of Silviculture at Universidade Federal do Amazonas - UFAM for their decisive assistance in this project. M.J. Ferreira acknowledges the research productivity grant- $\mathrm{PQ}$ provided by $\mathrm{CNPq}$ (process \# 309870/2020-8).

\section{REFERENCES}

Akers, M.K.; Kane, M.; Zhao, D.; Teskey, R.O.; Daniels, R.F. 2013. Effects of planting density and cultural intensity on stand and crown attributes of mid-rotation Loblolly Pine plantations. Forest Ecology and Management, 310: 468-475.

Alvares, C.A.; Stape, J.L.; Sentelhas, P.C.; de Moraes Gonçalves, J.L.; Sparovek, G. 2013. Köppen's climate classification map for Brazil. Meteorologische Zeitschrift, 22: 711-728.

Benomar, L.; DesRochers, A.; Larocque, G.R. 2012. The effects of spacing on growth, morphology and biomass production and allocation in two hybrid poplar clones growing in the boreal region of Canadá. Trees, 26: 939-949.

Borém, A.; Lopes, M.T.G.; Clement, C.R. 2009. Domesticação e Melhoramento: Espécies Amazônicas. UFV, Viçosa, 317p.

Botelho, S.A. 1997. Espaçamentos. In: Scolforo, J.R.S. (Ed.). Manejo Florestal. UFLA/FAEPE, Lavras, p.381-406.

Brasil, E.C.; Cravo, M.S.; Viégas, I.J.M. 2020. Recomendações de Calagem e Adubação Para o Estado do Pará. 2nd ed. Embrapa, Brasília, 419p. 
Comfort, E.J.; Roberts, S.D.; Harrington, C.A. 2010. Midcanopy growth following thinning in young-growth conifer forests on the Olympic Peninsula Western Washington. Forest Ecology and Management, 259: 1606-1614.

Cronkleton, P.; Guariguata, M.R.; Albornoz, M.A. 2012. Multiple use forestry planning: timber and Brazil nut management in the community forests of Northern Bolivia. Forest Ecology and Management, 268: 49-56.

Dionisio, L.F.S.; Araújo, H.X. de; Correia, R.G.; Martins, W.B.R.; Costa, J.S. da; Maciel, F.C. da S. 2018. Influência do primeiro desbaste na morfometria de Tectona grandis L.F. em Roraima. Floresta e Ambiente, 25: e00118214.

Dos Santos, V.A.H.F.; Ferreira, M.J. 2020. Initial establishment of commercial tree species under enrichment planting in a Central Amazon secondary forest: Effects of silvicultural treatments. Forest Ecology and Management, 460: 117822.

Durlo, M.A.; Denardi, L. 1998. Morfometria de Cabralea canjerana, em mata secundária nativa do Rio Grande do Sul. Ciência Florestal, 8: 55-66.

Dyer, M.E.; Burkhart, H.E. 1987. Compatible crown ratio and crown height models. Canadian Journal of Forest Research, 17: 572-574.

Ferreira, M.J.; Gonçalves, J.F. de C.; Ferraz, J.B.S. 2012. Crescimento e eficiência do uso da água de plantas jovens de castanheira-daamazônia em área degradada e submetidas à adubação. Ciência Florestal, 22: 393-401.

Ferreira, M.J.; Gonçalves, J.F. de C.; Ferraz, J.B.S.; dos Santos Junior, U.M.; Rennenberg, H. 2016. Clonal variation in photosynthesis, foliar nutrient concentrations, and photosynthetic nutrient use efficiency in a Brazil nut (Bertholletia excelsa) plantation. Forest Science, 62: 323-332.

Fox, J.; Weisberg, S. 2019. An R Companion to Applied Regression. 3rd ed. SAGE, Thousand Oaks, 802p.

Harrington, T.B. 2001. Silvicultural Approaches for Thinning Southern Pines: Method, Intensity, and Timing. Georgia Forestry Commission technical document no. FSP002, Warnel School of Forestry Resources, Macon, 17p.

Higuchi, N.; Santos, J. dos; Ribeiro, R.J.; Minette, L.; Biot, Y. 1998. Biomassa da parte aérea da vegetação da Floresta Tropical úmida de terra-firme da Amazônia Brasileira. Acta Amazonica, 28: 153-166.

Hoch, L.; Pokorny, B.; de Jong, W. 2009. How successful is tree growing for smallholders in the Amazon? International Forestry Review, 11: 299-310.

IBGE. 2019. Base vetorial de pedologia do Brasil: escala 1:250.000. (https:/geoftp.ibge.gov.br/informacoes_ambientais/pedologia/ vetores/escala_250_mil/versao_2019/Brasil_pedo_area.zip). Accessed on 22 Feb 2021.

INMET. 2020. Banco de dados meteorológicos para ensino e pesquisa. (http://www.inmet.gov.br/portal/index.php?r=bdmep/ bdmep). Accessed on 10 Apr 2020.

Inoue, M.T.; Filho, A.F.; Lima, R. 2011. Influência do espaço vital de crescimento na altura e diâmetro de Pinus taeda L. Scientia Forestalis, 39: 377-385.
Kainer, K.A.; Wadt, L.H.O.; Staudhammer, C.L. 2007. Explaining variation in Brazil nut fruit production. Forest Ecology and Management, 250: 244-255.

Leite, H.G.; Nogueira, G.S.; Moreira, A.M. 2006. Efeito do espaçamento e da idade sobre variáveis de povoamentos de Pinus Taeda L. Revista Árvore, 30: 603-612.

Leites, L.P.; Robinson, A.P.; Crookston, N.L. 2009. Accuracy and equivalence testing of crown ratio models and assessment of their impact on diameter growth and basal area increment predictions of two variants of the Forest Vegetation Simulator. Canadian Journal of Forest Research, 39: 655-665.

Lima, R.; Souza, C.R. 2014. Recomendação de Espaçamento para Produção de Madeira de Castanha-do-Brasil (Bertholletia excelsa Humb. et Bonpl.) para Plantios em Áreas Alteradas no Amazonas. Comunicado Técnico 110. Embrapa Amazônia Ocidental, Manaus, 6p.

Locatelli, M.; Marcante, P.H.; Cipriani, H.N.; Martins, E.P.; Vieira, A.H. 2015. Avaliação do crescimento da Castanha-do-Brasil Bertholletia excelsa BONPL. em um plantio no município de Machadinho do Oeste - Rondônia. Enciclopédia Biosfera, 11: 457-470.

Lopes, J. de S.; da Costa, K.C.P.; Fernandes, V.S.; Gonçalves, J.F. de C. 2019. Functional traits associated to photosynthetic plasticity of young Brazil nut (Bertholletia excelsa) plants. Flora, 258: 151446.

Machado, S.A.; Figueiredo Filho, A. 2006. Dendrometria. 2nd ed. Editora Unicentro, Guarapuava, 316p.

Mendiburu, F. 2020. Agricolae: Statistical procedures for agricultural research. R package version 1.3-3. (https://CRAN.R-project.org/ package=agricolae).

Nunes, S.; Gastauer, M.; Cavalcante, R.B.L.; Ramos, S.J.; Caldeira, C.F.; Silva, D.; et al. 2020. Challenges and opportunities for large-scale reforestation in the Eastern Amazon using native species. Forest Ecology and Management, 466: 118120.

Oliveira, M.V.T. 2000. Artificial regeneration in gaps and skidding trails after mechanised forest exploitation in Acre, Brazil. Forest Ecology and Management, 127: 67-76.

Oliveira, I.R.; Chagas, M.P.; Bouillet, J.-P.; Longui, E.L.; Lima, I.L.; Bordron, B.; et al. 2018. Effect of tree spacing on growth and wood density of 38-year-old Cariniana legalis trees in Brazil. Southern Forests, 80: 311-318.

Onyekwelu, J.C.; Stimm, B.; Evans, J. 2011. Plantation Forestry. In: Günter, S.; Weber, M.; Stimm, B.; Mosandl, R. (Eds.). Silviculture in the Tropics. v.8. Springer, Heidelberg, Berlin, p.399-454.

Poorter, L.; Bongers, F.; Aide, T.M.; Zambrano, A.M.A.; Balvanera, P.; Becknell, J.M.; et al. 2016. Biomass resilience of Neotropical secondary forests. Nature, 530: 211-214.

R Core Team. 2020. R: A Language and Environment for Statistical Computing. R Foundation for Statistical Computing, Vienna, Austria. (https://www.R-project.org/).

Rolim, S.G.; Piña-Rodrigues, F.C.M.; Piotto, D.; Batista, A.; Freitas, M.L.M.; Junior, S.B.; et al. 2019. Research Gaps and Priorities in Silviculture of Native Species in Brazil. Working paper, WRI Brasil, São Paulo, 44p. 
Ronquim, C.C. 2010. Conceitos de Fertilidade do Solo e Manejo Adequado Para as Regiöes Tropicais. Embrapa, Campinas, 26p.

Sanquetta, C.R.; Corte, A.P.D.; Mognon, F.; Maas, G.C.B.; Rodrigues, A.L. 2014. Estimativa de carbono individual para Araucaria angustifolia. Pesquisa Agropecuária Tropical, 44: 01-08.

Sanquetta, C.R.; Arce, J.E.; De Mello, A.A.; Da Silva, E.Q.; Filho, N.B.; Matoski, S.L.S. 2003. Produção de madeira livre de nós em povoamentos de Pinus taeda em função da densidade de plantio. Cerne, 9: 129-140.

Schneider, P.R.; Finger, C.A.G.; Schneider, P.S.P.; Fleig, F.D.; Cunha, T.A. da. 2015. Influência do espaçamento no autodesbaste de povoamento monoclonal de Eucalyptus saligna Smith. Ciência Florestal, 25: 119-126.

Scoles, R.; Gribel, R.; Klein, G.N. 2011. Crescimento e sobrevivência de castanheira Bertholletia excelsa Bonpl. em diferentes condiçôes ambientais na região do rio Trombetas, Oriximiná, Pará. Boletim do Museu Paraense Emílio Goeldi. Ciências Naturais, 6: 273-293.

Scoles, R.; Canto, M.S.; Almeida, R.G.; Vieira, D.P. 2016. Sobrevivência e frutificação de Bertholletia excelsa Bonpl. em áreas desmatadas em Oriximiná, Pará. Floresta e Ambiente, 23: $555-564$.

Scoles, R.; Gribel, R. 2021. Growth and survival over ten years of Brazil-nut trees planted in three anthropogenic habitats in northern Amazonia. Acta Amazonica, 51: 20-29.

Scoles, R.; Nicolau Klein, G.; Gribel, R. 2014. Crescimento e sobrevivência de castanheira (Bertholletia excelsa Bonpl., Lecythidaceae) plantada em diferentes condiçôes de luminosidade após seis anos de plantio na região do rio Trombetas, Oriximiná, Pará P. Boletim do Museu Paraense Emílio Goeldi. Ciências Naturais, 9: 321-336.
Smith, W.D.; Strub, M.R. 1990. Initial Spacing: How Many Trees To Plant. In: Duryea, M.L.; Dougherty, P.M. (Ed.). Forest Regeneration Manual. v.36. Springer Netherlands, Dordrecht, p.281-289.

Souza, C.S.C.R.; Dos Santos, V.A.H.F.; Ferreira, M.J.; Gonçalves, J.F.D.C. 2017. Biomassa, crescimento e respostas ecofisiológicas de plantas jovens de Bertholletia excelsa Bonpl. submetidas a diferentes níveis de irradiância. Ciência Florestal, 27: 557-569.

Tonini, H.; Arco-Verde, M.F. 2005. Morfologia da copa para avaliar o espaço vital de quatro espécies nativas da Amazônia. Pesquisa Agropecuária Brasileira, 40: 633-638.

Tonini, H.; Arco-Verde, M.F.; Sá, S.P.P. 2005. Dendrometria de espécies nativas em plantios homogêneos no Estado de Roraima - Andiroba (Carapa guianensis Aubl), Castanha-do-Brasil (Bertholletia excelsa Bonpl.), Ipê-roxo (Tabebuia avellanedae Lorentz ex Griseb) e Jatobá (Hymenaea courbaril L.). Acta Amazonica, 35: 353-362.

Tonini, H.; Kaminski, P.E.; Costa, P. da. 2008. Relação da produção de sementes de castanha-do-Brasil com características morfométricas da copa e índices de competição. Pesquisa Agropecuária Brasileira, 43: 1509-1816.

Walters, B.B.; Sabogal, C.; Snook, L.K.; Almeida, E. de. 2005. Constraints and opportunities for better silvicultural practice in tropical forestry: an interdisciplinary approach. Forest Ecology and Management, 209: 3-18.

Will, R.; Hennessey, T.; Lynch, T.; Holeman, R.; Heinemann, R. 2010. Effects of planting density and seed source on loblolly Pine Stands in southeastern Oklahoma. Forest Science, 56: 437-443.

RECEIVED: $22 / 08 / 2020$

ACCEPTED: $23 / 04 / 2021$

ASSOCIATE EDITOR: Francesco Ripullone 